\title{
X線マイクロアナライザ
}

中 村 忠 啨*

\section{On Electron Probe Microanalyser}

\section{Tadaharu NAKAMURA}

\section{1. 緒言}

この数年間においての分析機器の発展にはおど万くべ きものが多い。同時に感度および精度の向上も著るしい あのがある。したがつて、各研笁分野において微量成分 の分析が容易となつたため、従来難点であつた微量成分 の検討が推測の域を脱つしうるようになつた。しかし、 研究の進展ととあに微量成分の所在が問題点となつて来 た。すなわち、现在まで微量成分として示されて来た数值 は、ほとんどの場合試料中に含有されている元素の平均 值的なものであり、笑際には均一に分布されているすす か、局部的に主成分として所在しているのか判断しがた いうらみがあつた。また、元素の分布状態を知るどとは まつたく困難なととともいえる。そこで、焱光分光分析: あるいはX 線分析なよ゙により局部分析が行なわれるよう になつたが、その分析範囲は $\mathrm{n} \times 10$ ミクロン程度以上で あり、しかも測定試料は破損し原 形を保つ事は難かしいととであ る。さらに極微量な試料あるいは 10 ミクロン程度以下の局部の分析 は殆ど不问能な状態であつた。そ れらの難点と煩雑さをさけ、比較 的容易に測定をなしうるあのとし て X 線マイクロアナライザーの有 効性が認められるようになつて来 た。この分析装罚の本所的な利点 を示すと、電子プローブを用いて ミクロン程度の極微細部の定性分 析および定量分析が可能である。 また、非破猡的に測定が行なえ、 さらに電子プローブを走查するこ とにより、試料表面の元素の分布 を容易に観察するてとができ、な お迅速性むある。在来怪元素につ

受理 昭和 40 年 12 月 25 日

* 早稲田大学教育学部理学科地学教空 講即

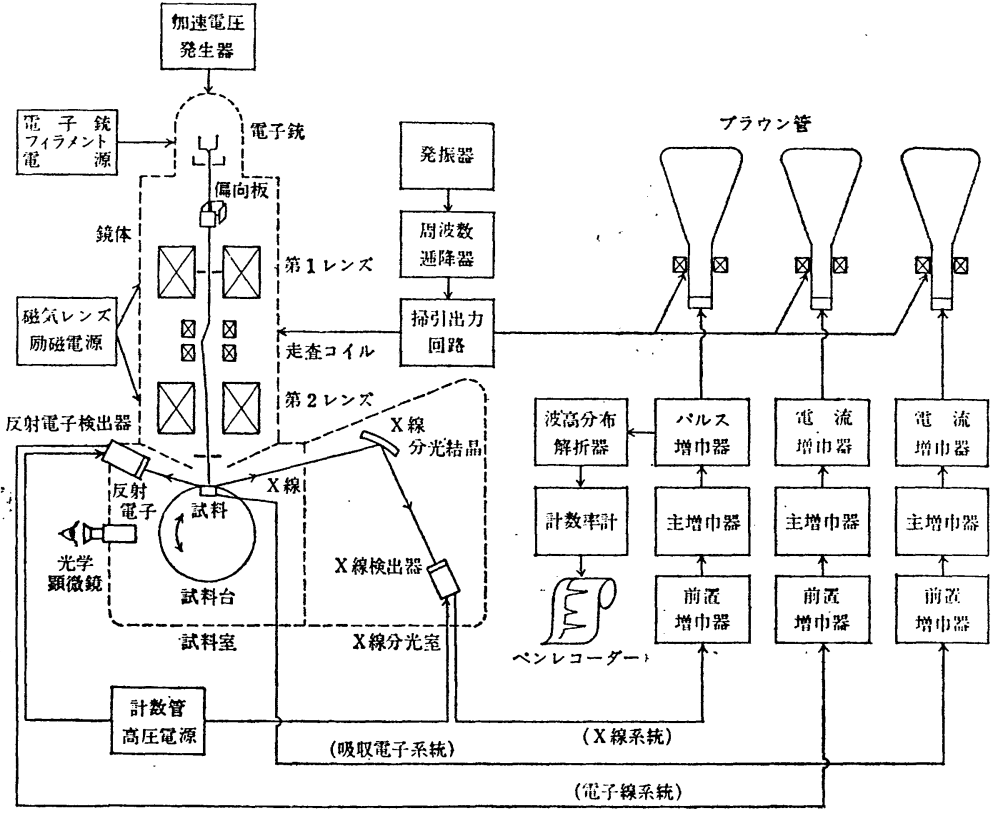

第1図 $\mathrm{X}$ 線マイクロアナライザーの系統図

No. 28 ('66一春) 
なされ、現今では局部的な改良を除いては充分な実用性 をもつ装置となつた。また、分析元素もナトリウム程 度までであつたが現在では、さらに原子番号の小さい軽 元素についてあ分光結晶などの研究も進み炭素・窒素そ してべリリウムにいたるまでの測定が可能となりつつあ る。本装置の測定機構の要約を示すと、まづ電子銃より 発射させた電子を $1 \sim 0.3$ ミクロン程度に紋り試料面上 に照射し、1立方ミクロン程度（約 $10^{-\mathbf{1 4}} \mathrm{g}$ ) より発生す る固有 $\mathbf{X}$ 線を利用し、螢光 $\mathbf{X}$ 線分析と同様に分光結晶を 用いて波長分離を行ない、その波長と強度を測定して、 定性分析あるいは定量分析を行なうあのである。すなわ ち試料中に存在する各元素加ら発生した固有 $\mathbf{X}$ 線をもち いて元素分析する物理的分析法である。分析方法として は、電子プローブを(任意の一点に静止 ${ }^{2)}$ する点分析、 試料移動によるか電子プローブを一直線上に走查する線 分析、また、イギリスの Cosslett ${ }^{3 \sim 9}$ ) らにより開発され たもので、電子プローブを二次元的に走查し、試料より
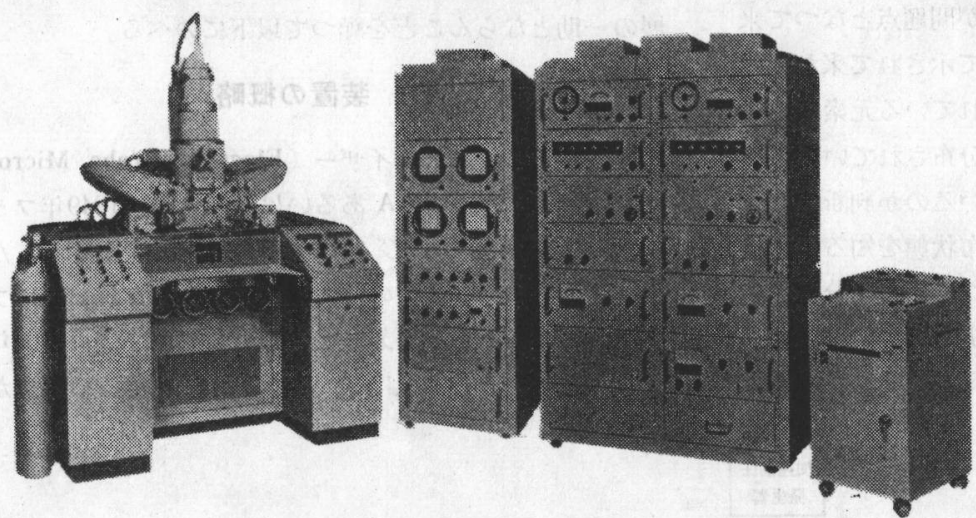

第2図 J X A - 3 A 型日本電

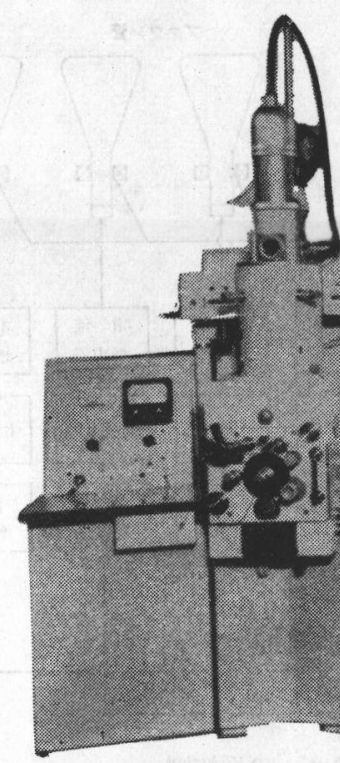

子製
発生した固有 $\mathrm{X}$ 線の強度をブラウン管上に輝度変調して 像を画加せ試料面上の元素分布を影像として観察する面 分析などがある。本装置の原理については、国内にて、 市の川竹男氏 ${ }^{10)}$ 、紀本静雄氏 ${ }^{11)}$ 氏らが詳細に述べてい るので簡単に記しておく。〔図1〕は走査型 $\mathrm{X}$ 線マイク ロアナライザーの系統図の一例で、いずれの装置も原理 的には全く同様である。装置を大別すると次のようにわ けられる。

1. 電子光学系 2 . 試料室 $3 . \mathrm{X}$ 線分光器

4. 電子管回路

この分類にしたがつて実際の分析に必要と思われる程 度の説明は筆者が「化学の領域増刊60号・X 線工業分析 」に記しているのでこてでは詳略する。測定に用いてい る装置の全体は参考として〔図 2 〕〔図 3 〕示してお <。

\section{3. $\mathbf{X}$ 線の発生}

電子プローブを試料に照射し た場合に、電子と物質との間に 生じる物理的現像を〔図 4〕の ごとくCosslett は示している。 実際については多成分系物質で あるためまことに複雑であり、 特にてれらの諸現象が定量分析 において問題点となつてくる。 故に簡単ではあるが説明してお く。電子エネルギーが $\mathbf{X}$ 線エネ ルギーに変換する割合は僅かで 殆どが熱エネルギーに変換され る。すなわち $\mathrm{X}$ 線の輻射効率を

第 3図 T R A - 25A 型明石製 


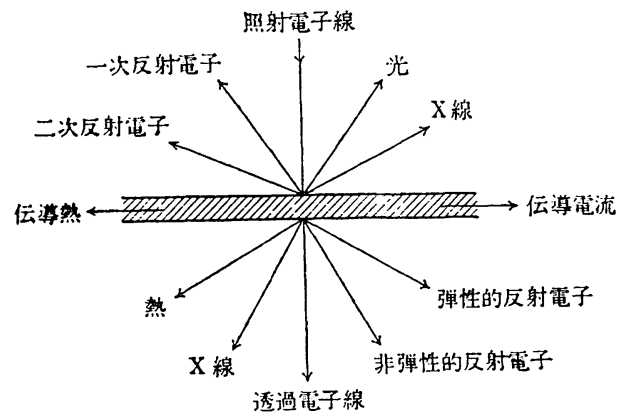

第 4 図 電子之物犋との諸物理的現象

(V. E. Cosslett)

吕) とすれば次の関係がある。

$$
\eta=\mathrm{C} \mathrm{Z} \mathrm{V}
$$

$\mathrm{Z}$ は原子番号、 $\mathrm{V}$ は電子線の加速電圧 $(\mathrm{K} \mathrm{V}$ 単位) $\mathrm{C}$ は 定数で約 $1 \times 10^{-6}$ である。これを普通の測定条件で考虑 すると、X線への変换エネルギーは入射電子線エネルギ 一の $1 \%$ 以下となる。また物犋中を通過してゆく電子が 固有X線励起によるエネルギーの損失を Webster は次 のごとき関係をあたえている。これは物質 $1 \mathrm{~cm}$ あたり のエネルギー損失を示す。

$$
\mathrm{dE} / \mathrm{dx}=\mathrm{k} \beta^{-1.4} \rho_{\mathrm{A}} 2\left(Z_{\mathrm{A}} / \mathrm{A}\right)
$$

$k$ は常数、 $\rho_{\mathrm{A}}$ は電子照射点の密度、 $\mathrm{A}$ は $\mathrm{A}$ 元素の原 子量、 $\beta$ は光速度との速度比、 $Z_{\mathrm{A}}$ は $\mathrm{A}$ 元素の原子番 号、ただしA元素が $100 \%$ の場合である。さらに入射し た電子の到達深度は前式より次の関係式をうる。

$$
R_{\mathrm{m}}=\mathrm{k}\left(\mathrm{E}^{1.7}-\mathrm{E}_{\mathrm{KA}}{ }^{1.7}\right) \mathrm{A} / \rho_{\mathrm{A}} Z_{\mathrm{A}}
$$

$R_{m}$ は電子の到達深度 (ミクロン)、 $\mathrm{E}$ は加速電压、 $\mathrm{E}_{\mathrm{KA}}$ は $\mathrm{A}$ 元素の $\mathrm{X}$ 線励起電压、 $\rho_{\mathrm{A}}$ は $\mathrm{A}$ 元素の電子照射 点の密度、 $\mathrm{Z}_{\mathrm{A}}$ は $\mathrm{A}$ 元素の原子番号、 $\mathrm{A}$ は $\mathrm{A}$ 元素の原子 量である。普通の测定条件においての電子到達深度は約 1 ミクロン程度といわれている。また発生する固有 $\mathrm{X}$ 線 強度と濃度との関係はむつとあ単純汇考えるならば、そ れぞれの固有 $\mathbf{X}$ 線強度を測定し、純元素の $\mathbf{X}$ 線强度との 比を求め机ば知ることができる。すなわち同測定条件 において、未知試料中に含まれる元素 $\mathrm{A} の \mathbf{X}$ 線強度を

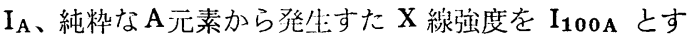
れば、試料中の元素 $\mathrm{A}$ の濃度 $\mathrm{C}_{\mathrm{A}}$ は次のでとくである。

$$
\mathrm{C}_{\mathrm{A}}=\mathrm{I}_{\mathrm{A}} / \mathrm{I}_{100 \mathrm{~A}}
$$

しかし、実際においては試料の殆どは多成分系物質の ため、吸収効果および二次螢光 $\mathrm{X}$ 線励起効果などによる 共存元素の影響13) があり、現在多くの検討がなされ、 涨度との関係を辀細に示そうとしている。しかし、その 班象は複雑であり、煩雜さをさけることができず允分と はいい難い現況である。

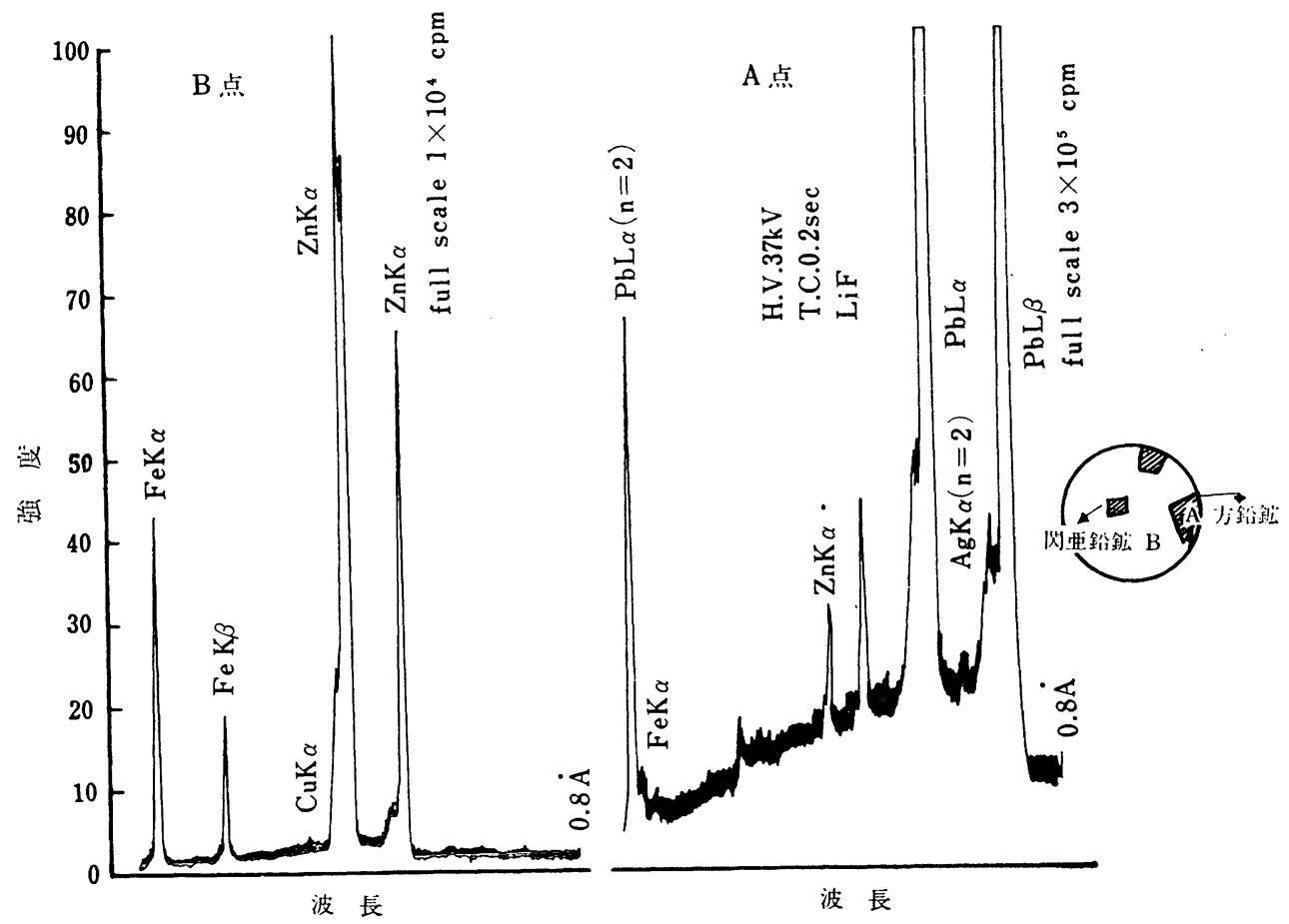

第 5 図 研磨による鈗物種怕互の污染の可能性

No. 28 ('66一春) 


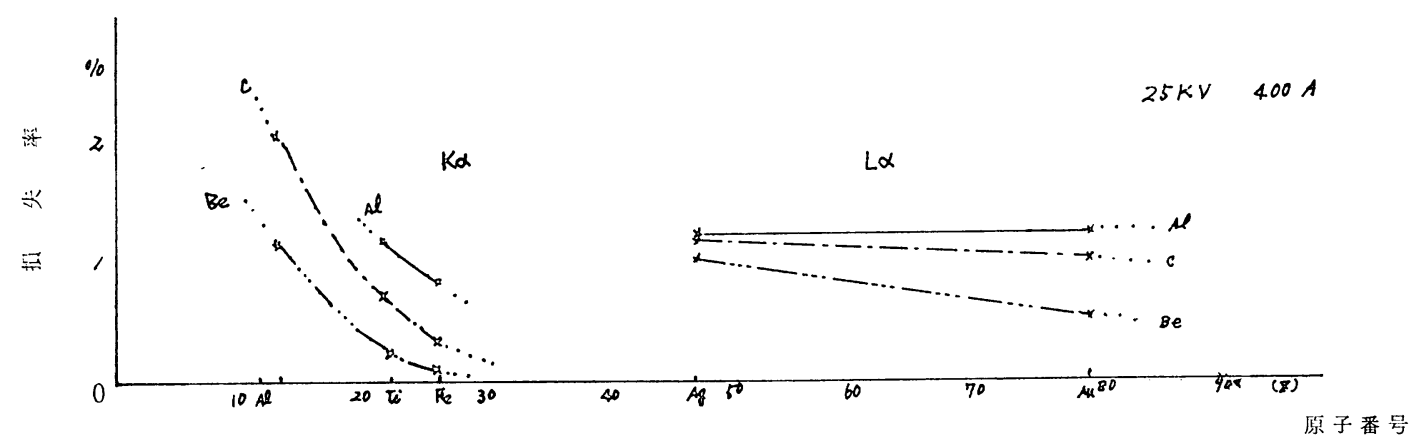

第 6 図 蒸着の盉類とX 線強度の損失率

\section{Q. 試料の前処理}

金属と異り、鉣物試料は一般に熱伝導性、電導性が悪 るく、特に硫化鉱物、炭陵塭鉱物では、電子線照射によ り熟分解を乣じる場合がある。また入射した電子が過飽 和となり、放電して测定が不们能となるととがある。さ らに装酳の機構上のため、試料表面の凹凸の程度屯考虑 する必要がある。このため試料の前処理 $\left.{ }^{44}\right)$ が兮分でな いと尔析の精度はもとより測定にも困難を尘ずる。

\section{1 . 試料研磨}

最近の装置はX 線の取り川し角度が大となり凹凸への 洘麀は初期に比較して割合に安吻となつてきた。契用化 されてはいないがX線の取りけし角度が $90^{\circ}$ の場命、回 円が平面より $\mathrm{n} \times 10$ ミクロン程度においてもその影響が 殆どないとの報告15) がある。実測にあたり常法にて研 禁し反射顕微鏡で 100 倍程度で観察し、おおむね平滑と なつていれば允分测定するととができる。测定位沙が判 つている場合はその部分が充分半滑であれば測定ができ る。埸命によつては、第、四凸が測定位䍜の目標となり、 容吻に位置の選定が行なえる利点もある。試料研磨に際 し特に留意すべきととは研磨剂の污染である。すなわ ち、軟弱な鉱物琹、龟裂などのある場合、使用した研磨 剂が埋め込まれ、䛊測をする危険がある。したがつて本 装罚による测定試料はダイヤモンドペーストによるのが 㖩あ良いととであり、同時に研磨す容易に完了する。一般 に鉱不のような試料は軟鉱物種と硬鉱物桓が共在してい るため砸磨のときに、これら鉱物自身が微細粉末となり 污染となるととが考えられる。この污染は研磨する以上 さけるのは不闭能なととである。特にミクロン以下であ る莂合は測定時において判別することは全くできないて とである。したがつて、测定以前に試料面の鉱物㮔あるい

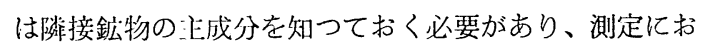
いて共存する元素については充分注意をしなければなら ない。その一例を[図5]に示す。これは则两鉛鉱と矢鉛 鈗とが隣接しているもので、方鉛鉱中に卌鉛が認められ
ているが、実存するものか、污染によるものか確認し難 いととである。ただし微量成分の場合の問題点であり主 成分の測定については、とのような考虑は無視できる。

\section{2 試料面の保護}

前述のごとく、試料の破損あるいは測定の困難を防ぐ ため、鉱物試料には必要なととである。これらは照射電 子流を小にすれば防止が问能となるが発生 $\mathrm{X}$ 線の強度が 小となり、検出器の感度外となる。したがつて現在では 一般に種々の影響を考虑される軽元素の蒸着により保萑 している。普通炭素の蒸着が行なわれているが、测定元 素の程類によつてはアルミニウムを蒸着してもよい。し かし、炭素の蒸着の埸命であ测定元素が軽元素であると 〔図 6〕に示すごとく蒸着膜の厚さが影響16〕するので 充分考䍐する必要がある。ふつう $500 \mathrm{~A}$ 程度が適当と思 う。また蒸着による影㗽は軽元素以外の满合は殆ど無視 でさる。

\section{3 試料の加工}

粉体試料・数十・クロンの少数試料についても分析が 问能であるが、測定するために加工せねばならない。粉 末試料が比較的多量ある埸合は川肘の樹脂にて混合加工 し研磨するのも一方法である。この埸会、電等性塗料で アースをとり、さらに蒸着をほどこす。また樹脂中に测 定に影響しない電導性物所（例えば金属粉）を泥入させ
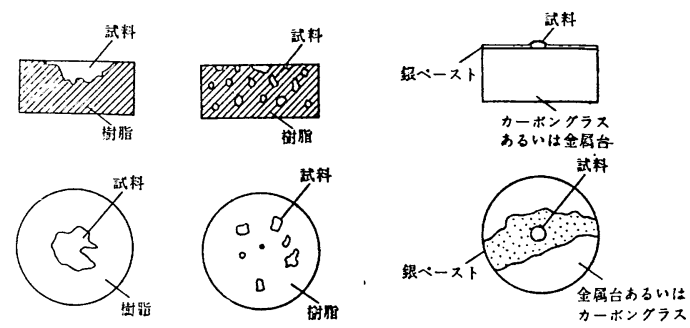

告料 1 粒が数ミリ以 上の大きさであれば 研罒が可能である。 小鉣物に心用

小粒子の誈料が多是 にある場合でとの一 部の校子が矿厢され る粉鉣に志用

試料一粒が 50 ミクロ ン程度の大きさで小 数の場合。宇宙暨な

第 7 図 試料調整のいろいろ 
るのも良い。それらの例を〔図 7〕に示す。

\section{5. 分析手段}

電子プローブを操作することにより次のような分析手 段がある。

1. 二次元似分析：隹として武料面」に:の元素分布を定 性的に観測するむのである。

2. 一次元啲分析：電子プローブを直線上に走社する か、電子プローブを静止:し試料を直線上に移動する分析 法で定性分析あるいは半定量的な測定がでさる。

3. 点分析：㫪之して定量分析の場会の手段であるが 定性分析にも重要な乎段である。

実測においては、上記の各乎法を目的に応じて適当に組 合わせて分析をおてなう。条分析手段の特徵を以下に示 す。

\section{1 二次元的分析（面分析）}

電子プローブを $\mathrm{X}$ 軸およびY $\mathrm{Y}$ 軸方向に走查し、試料表 面の、ある面積の分析をなすすので、分析しうる最大値 は装置により異るが $0.8 \times 0.8 \mathrm{~mm}$ 程度である。乙の場合 の試料面の情報はブラウン管け江像として観察する。反 射電子像 (back scatterd electron image) といわれる のは、試料表面に照射した電子が一部はねかえされる。 これをブラウン管上に像としたもので、試料表面の凹凸 および原子番号の大小などを観察できる。試料吸収電子 像 (absorbed electron image) とは、試料か吸収した 電子の流忆をブラウン管上像としたもので、原子番号 の大小を比較的容易に観測するととがでさる。また $\mathrm{X}$ 線 像 (X-ray image) は一元素の分布あるいは濃度の大小 を概略ではあるが観察することがでさる。これらの像は 総じて走查像（scanning image）といい、普通元素の 分布、他の測定で認为難たかつた特異部分の発見、さら に分析位置の確認または指定などに利用される。乙の走 查像のみで鉱物種の同定ができるととあある。

\section{2 一次元的分析（線分析）}

5. 1 の方法では走查面内の大要を知ることができるが 隣接する鉣物種の境界、あるいは微細任点在する物斦に ついて网確さがかける。またブラウン管上の輝度変調で は元素の変動を認办にくい場合がある。乙のような場合 電子プローブを目的の位置に操作し、一線上をゆつくり 走监し、ブラウン管上に一元素の $\mathrm{X}$ 線強度をシグナルと して迅速に観察するてとが出来る。てれは主成分のみで なく、微量の含有元素についての分析線上の分布および 変動がわかり、シグナルの高さから大体の蛂度を知り うる。分光系のチャンネルが複数の芬合は、定性的であ るが他元素との関連性を同時に測定でさ、迅速かつ容易 の利点を有するが精度は得られない。他方、電子プロー ブを静止し、試料微動による方法は時問を要するが精度
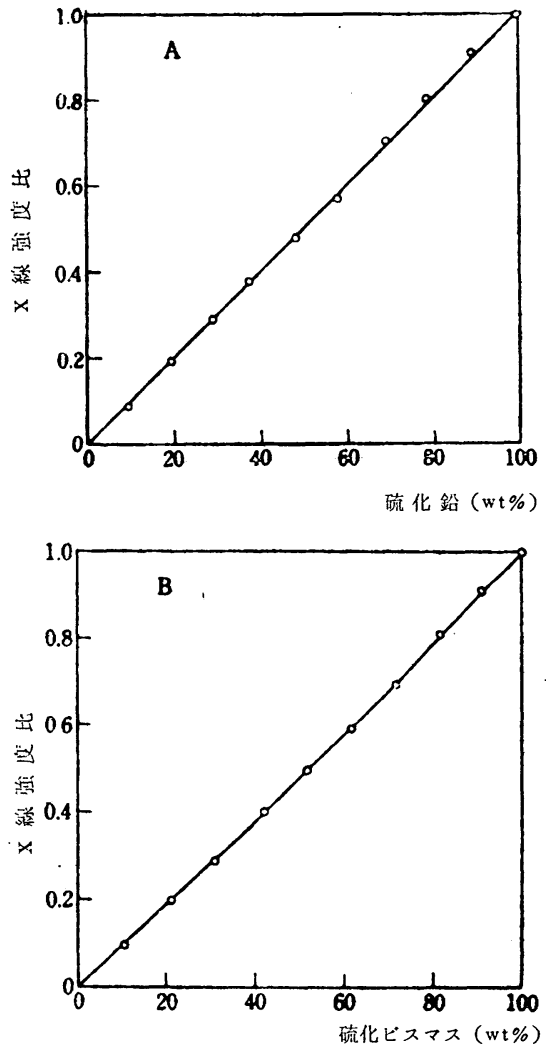

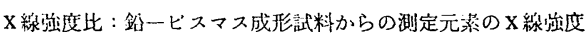
/祄硫化物成形武料からのX称強度测定条件：表 1 と同し

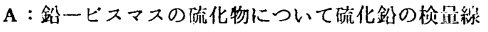
B : 鉛一ビスマスの流化物について硫化ピスマスの柃量總

第8図 硫化鉛一硫化ビスマスの検量線

表 1 粉末法による各檑成形試料の例

測定条件 $\mathrm{V}_{\mathrm{A}}: 25 \mathrm{kV} 、 \mathrm{Dp}:$ 約 $1 \mu 、 \mathrm{~S}: 600 \mu 、 \mathrm{~L}_{\mathrm{M}}$ : Co、 $\mathrm{Zn} 、 \mathrm{Mn} 、 \mathrm{Ti} 、 \mathrm{Cu}$ は $\mathrm{K} \alpha(\mathrm{n}=1) 、 \mathrm{~Pb}$, Bi は $\mathrm{L} \alpha(\mathrm{n}=1)$ 、Iabs : $0.1 \mu \mathrm{A} 、 \mathrm{Cy}: \mathrm{LiF}$ $(\mathrm{Pb}, \mathrm{Bi}): \mathrm{Mi}-\mathrm{ca}(\mathrm{Ti}):$ Quartz $(\mathrm{Zn}, \mathrm{Co}$, $\mathrm{Mn}, \mathrm{Cu}) 、 \mathrm{C}:$ プロポーショナル $(\mathrm{Ar} カ ゙$ 不使用)

$\mathrm{X}$ 線強度值：試料上 3 点の平均値 ばらつき $19 \%$ 以下 $\mathrm{I}_{100}$ ：純金属からの $\mathrm{X}$ 線強度、I：試料加らの $\mathrm{I}_{100}$ 之同元素の $\mathrm{X}$ 總強度

\begin{tabular}{lcccc} 
組 成 & 測定元素 & 理論値 & \multicolumn{1}{c}{$/ \mathbf{I}_{\mathbf{1 0 0}}$} & 誤差(\%) \\
$\mathrm{Co}_{2} \mathrm{O}_{3}$ & $\mathrm{Co}$ & 0.711 & 0.698 & -1.8 \\
$\mathrm{ZnO}$ & $\mathrm{Zn}$ & 0.803 & 0.803 & 0.0 \\
$\mathrm{MnO}_{2}$ & $\mathrm{Mn}$ & 0.632 & 0.629 & -0.5 \\
$\mathrm{TiO}_{2}$ & $\mathrm{Ti}$ & 0.601 & 0.601 & 0.0 \\
$\mathrm{CuO}$ & $\mathrm{Cu}$ & 0.799 & 0.791 & -1.0 \\
$\mathrm{PbS}$ & $\mathrm{Pb}$ & 0.866 & 0.849 & -1.1 \\
$\mathrm{Bi}_{2} \mathrm{~S}_{3}$ & $\mathrm{Bi}$ & 0.813 & 0.793 & -2.3
\end{tabular}

注 $\mathrm{I} / \mathbf{I}_{100}$ は第一近似值で吸収補正などを含まない。 
はよくなる。との場合も複数チャンネルであれば同時に

数元素の分布を記録でさ、他元素との関連性を明確に測 定できる利点がある。

\section{3 点分析}

組成不明の鉱物、ミクロン程度の極微細鉱物、または 局所の分析が行なえる。定性分析の場合は目的とする分 析点に電子プローブを静止させ、分光結晶を作動させて、
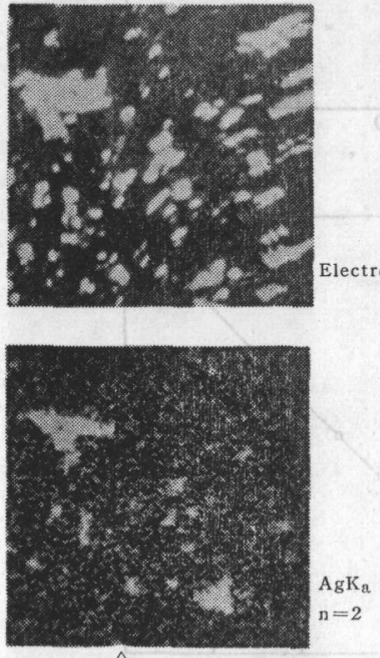

บิ
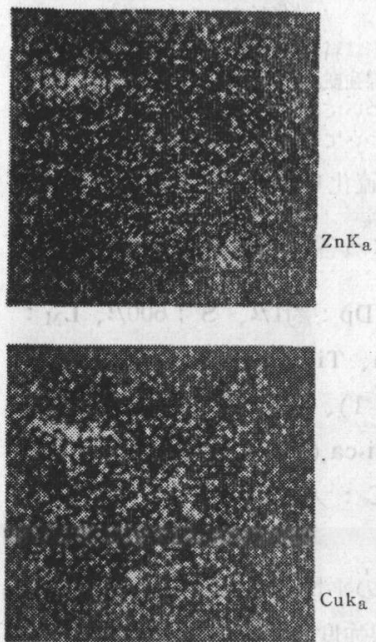

そのスペクトルを記録装置により画かせる。 定量分析を行なう場合は、分析元素の固有 $\mathrm{X}$ 線の波長に分光結晶を合わせ計数装置を用い てX線強度を測定する。

第10図隕石（線分析の例） 田上鉄隕石て Kamacite と Taenite の境界に二 ッケルが著量分布しているを総めた。エッチン グにより Kamacite と Taenitc の分布は判明 するが、ニッケルの分布は不明であり、興味あ る結果を得た。
第9図 硫化鉱物 清趇鉱山産の銀鉱石て銀鉱物は、 Argentite といわれている。X線 像でもわかるが、Argentite の部 分を点分析すると、新らたに銅、 亚鉛が珰められた。顕微鏡的には、 銀の分有はみとめ難いが、測定の 結果、その大きさは10ミクロン程 度で分布していることが判明した。

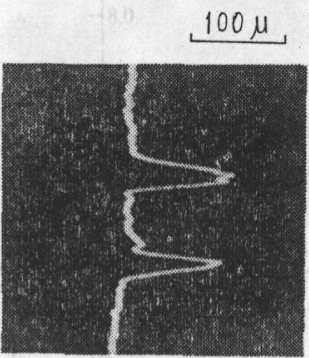

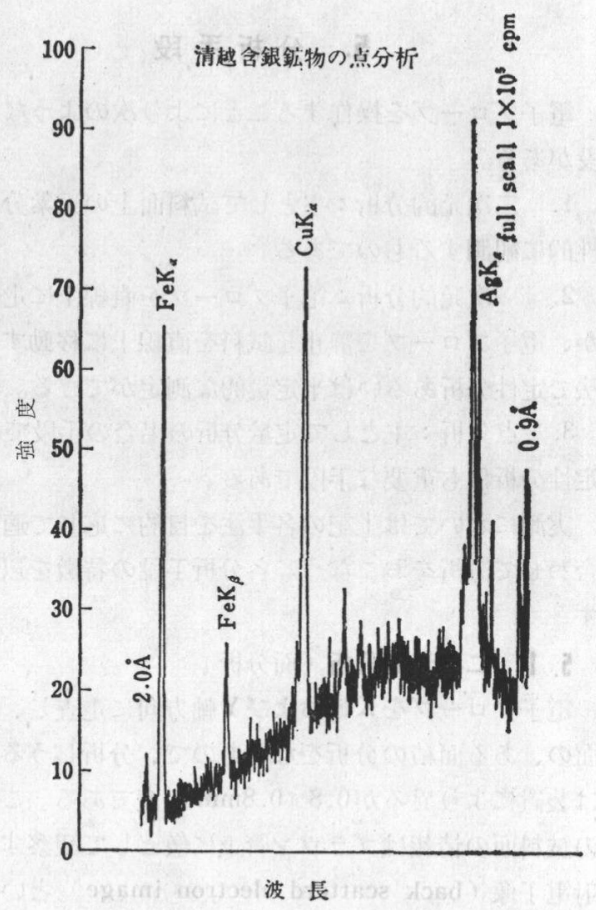

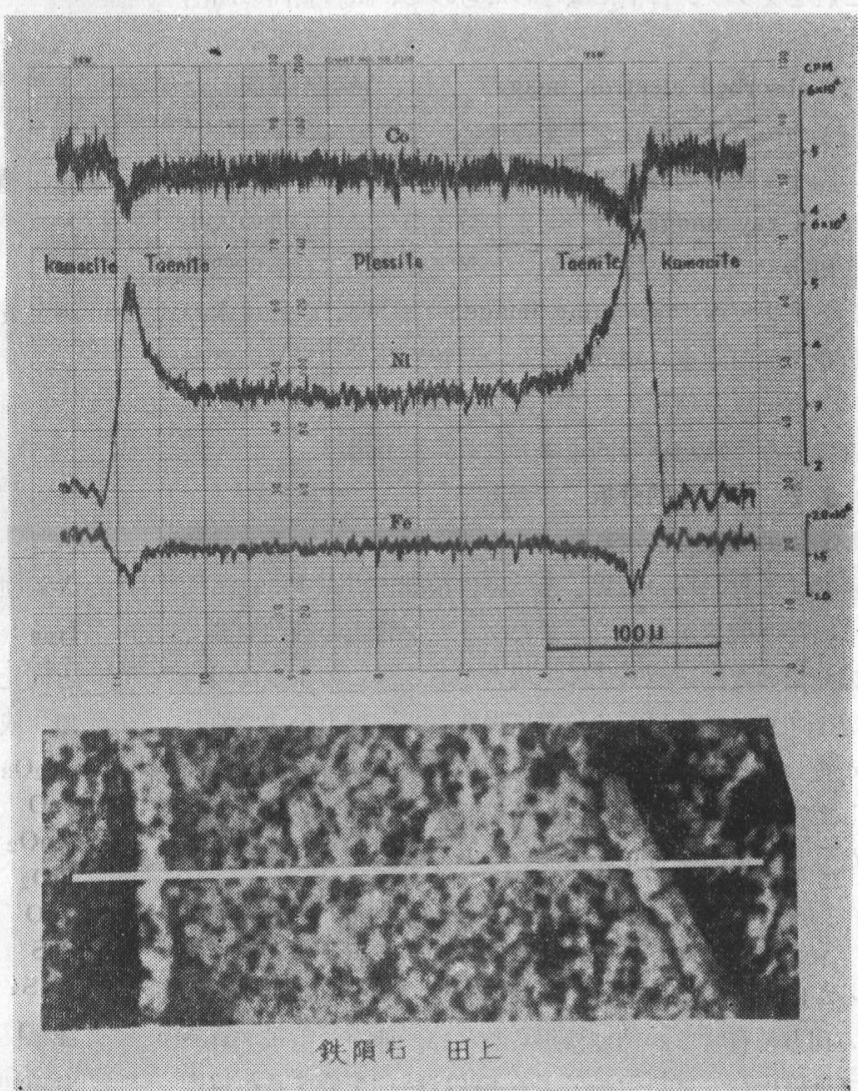


Electron

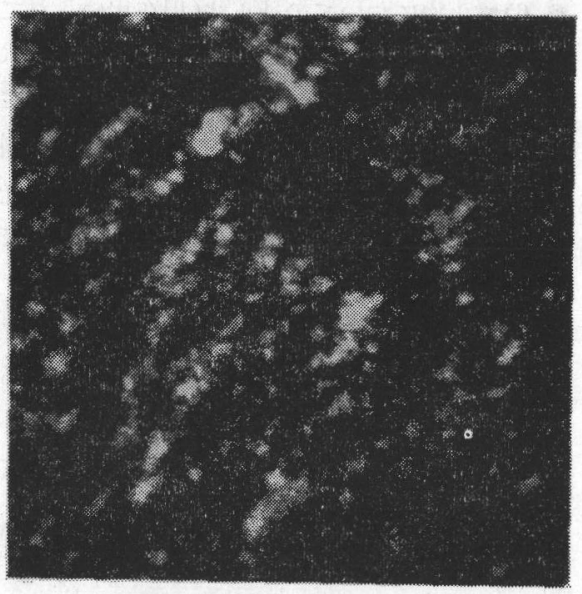

, is

$\mathrm{F}_{e} \mathrm{~K}_{a}$

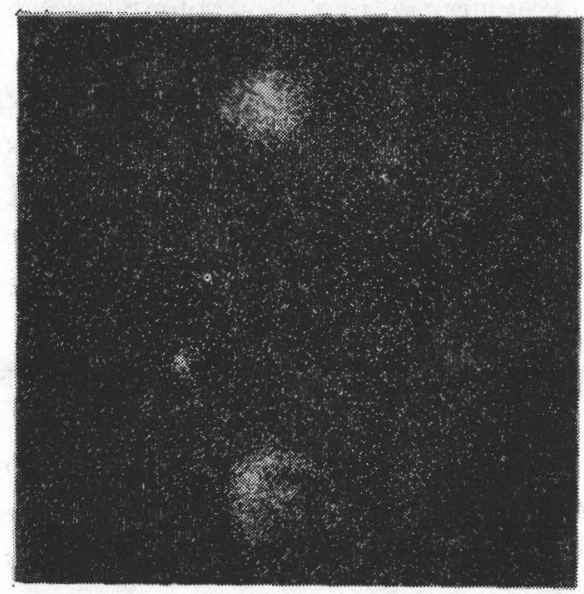

$S_{i} K_{a}$.

\section{6. 定性および定量分析}

定性分析については元素の濃度確認限界が問題である が、装置の型、電子照射条件、元素の種類、分光結晶の 種類、計数管の種類、共存する元素などの関係により多 くの問題があり、確認限界は $\mathrm{n} \sim 0.0 \mathrm{n} . \%$ の範囲におよ ぶ。最近では梌出器の改良により確認限界は一般に向上

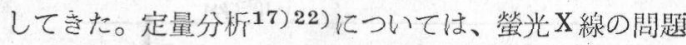
点と同㥞であり、Castaing ${ }^{18) 、 B i r k s}{ }^{19)}$ らの提案した

\section{第11図 粉塵}

東京上野附近で採集した武料である。粒度は約 $80 、 50 、 20$ ミクロンの 3 粒が测定面上にある。これは宇宙麼であるか否かの組成分析を行な った例である。測定結果は組成からみて、洷灰と思われる。

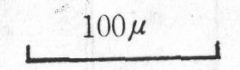

Line Anal

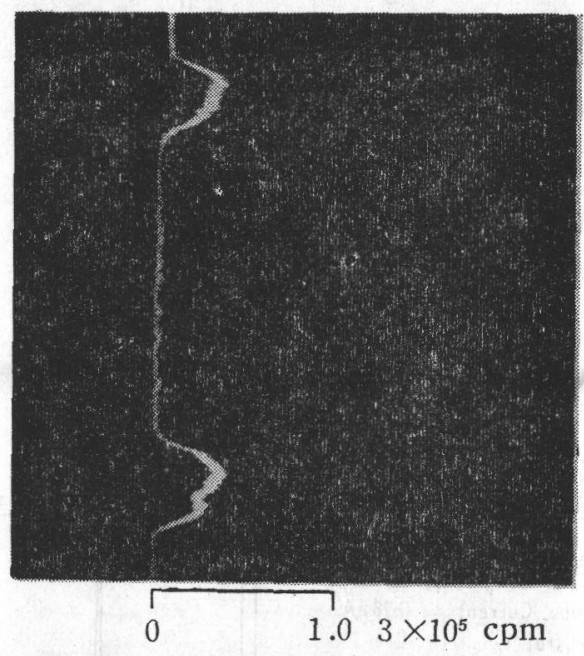

$\mathrm{I} / \mathrm{I}_{100} \mathrm{Fe}_{e}$
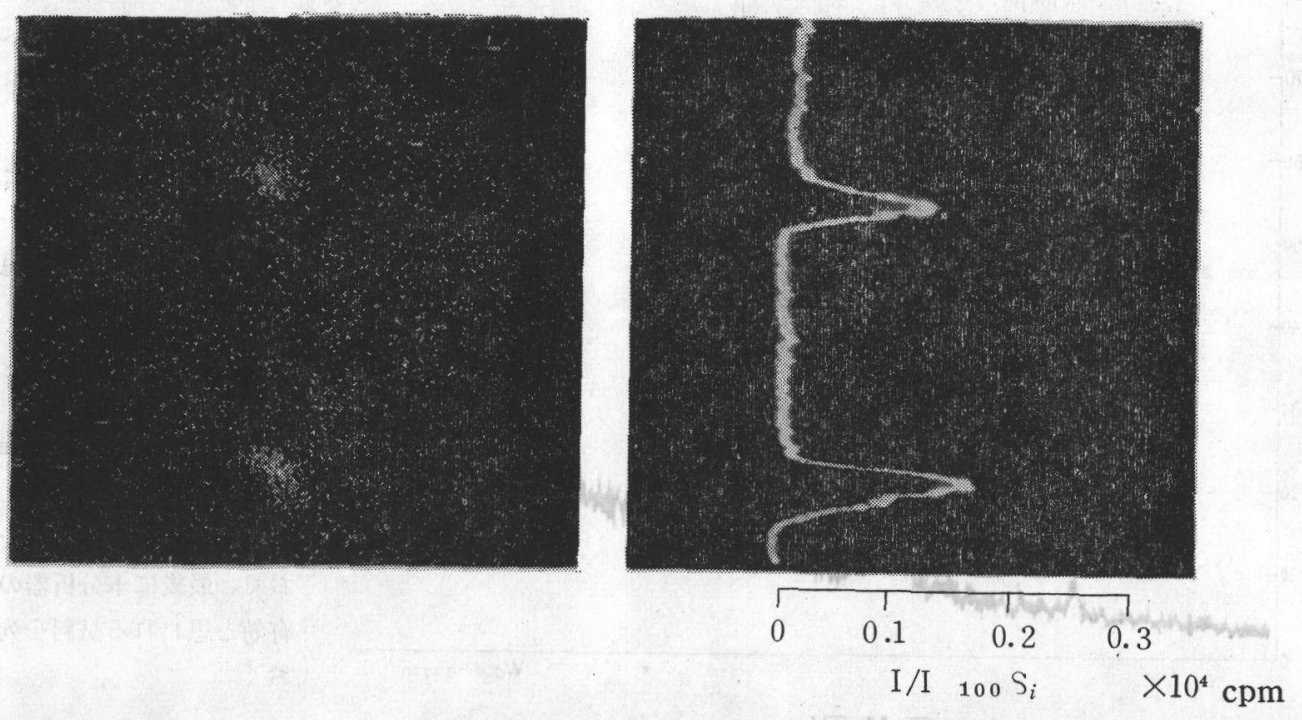
半理論的方法があ之になり现在多くの研究者が補正法に ついて研究されている。この利点は多くの標準試料を必 要としないことであるが、補正のために多くの手数をと あなう。その問题点の二・三をならべると、1)質量吸収係 数の信頼すべき値を得るとと2)二次螢光 $\mathrm{X}$ 線行起の関 係をうるとと 3)多成分系の補正法の簡只化 4)柽元素を

Point Analysis

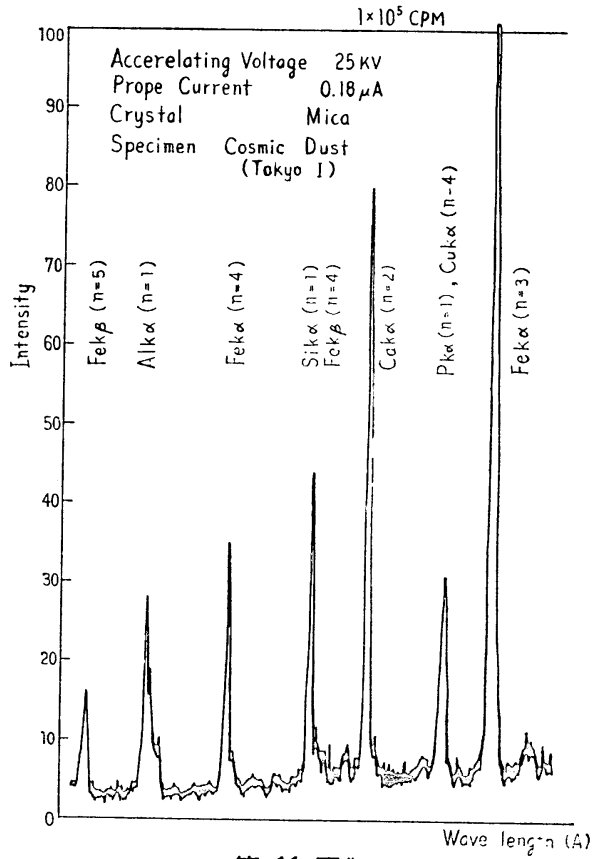

第 11 図"

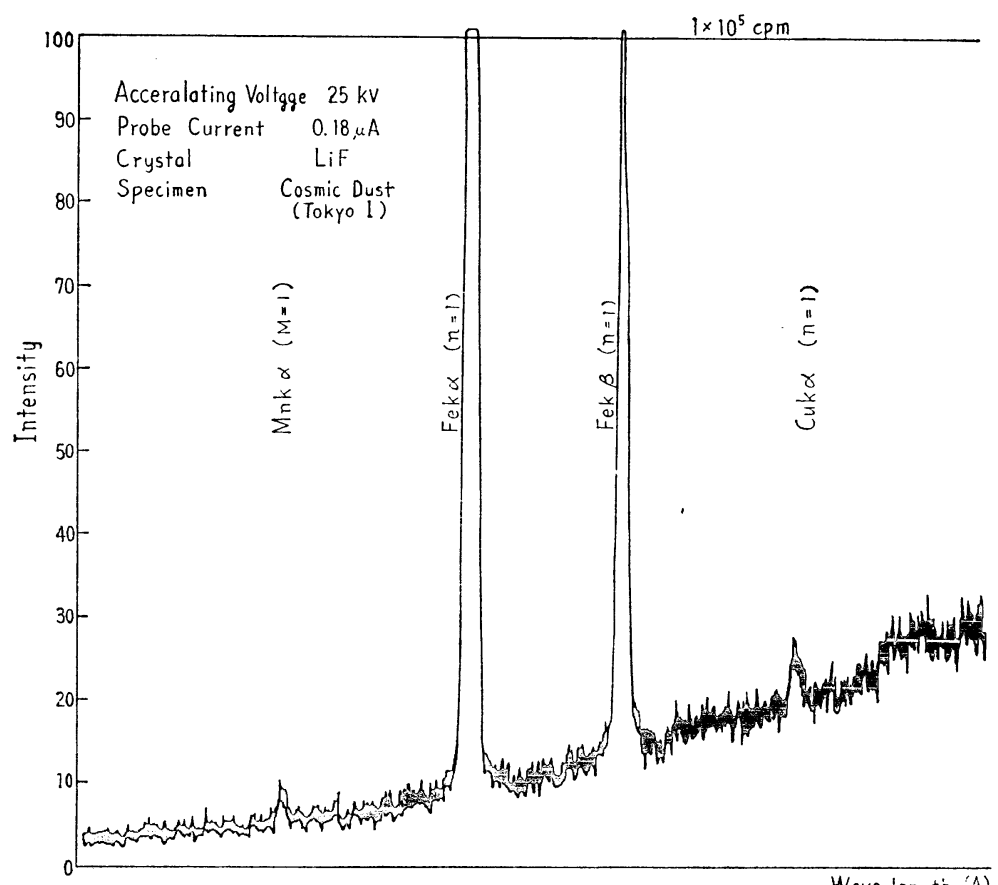

Ware lengtin (A)

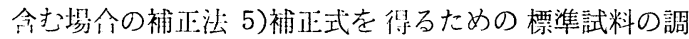
整 6)酸化物についての補正法(現在用いられている補正 法が一般にあてはまらない）7)試料の形状による種々の 関係などがあげら机る。それに対し標準試料による実験 的方法 ${ }^{20)}$ は未知試料之類似の組成の標準試料を多く作 製するめんどうはあるが、吸収效果、二次螢光励起効果 などの補正をせず容易に検量線をうるととがでさる。し かし電子プローブ径が 1 ミクロン以下であり、その X 線 癷珄が 1 ミクロン涼方程度以下のため、ミクロン以下 で均一な標準試料を調整するととに難点がある。筆者ら

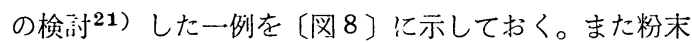
法による各利標準試料の例を〔表 1〕に示しておく。

\section{7. 応用}

鉱物への応用は具在までの報告では定州:啲なあのおよ ご断胡们なあのが多い。また報告も他に比較して少くな い。応用例を略記すると、試料中の微細鉱物の分析、あ るいは特異元素の分布などの局阔分析的なととがらであ る。たとえば、黄鉄鉱、黄銅鉱、ペントランド鉱、沙雨 鉛鉱などの硫化鉱物52 23254$)$ 中のニッケル、コバルトなど の分布あるいは狭雑物の分析、スズ不や磁鉄鉱などの陵 化鉱物 ${ }^{33 \sim 36)}$ の検郭、その外にニオプ、タンタル、白金

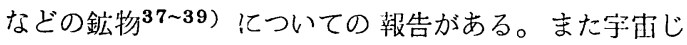
几、隕石などの研品55 51) 亿あ応用されている。興味が ある点は微細な物领の組成分析が可能となつてきたとと であり、㶱装罚の特徽を充分に活用しているもの之思 う。参若までに筆者のデータ中 より二・三の例を図 9 〜図13に 示し簡単に説明しておく。

\section{8. 結 び}

X線マイクロアナライザーの 概略と知際について述べてきた が、琴在允分なる分布もなく、 その利用篡围は狭いが、今後に おいて利用者の増加とともに、 諸問题点も解明され、一層有意 義任利用さ机るすのと思う。ま た X線マイクロアナライザーに 関する総介的な著書として L.

\section{S. Birks, "Electron Probe} Microanalysis" Chemical Analysis, Vol XVII (John Wiley \& Sons)(1963)を記して おく。最後に本分析器の測定に 有効と思われる試料を列挙して おく。 


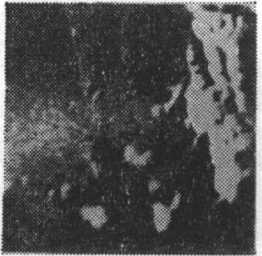

Electron

影微鏡観察では黄銅鉱 の所在は認めがたい。

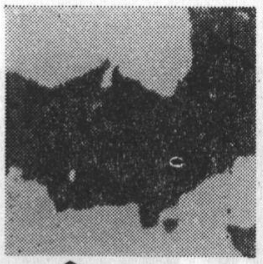

$\mathrm{FeK} \alpha$

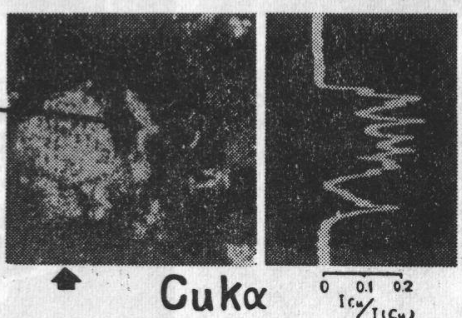

Cuk $\alpha$

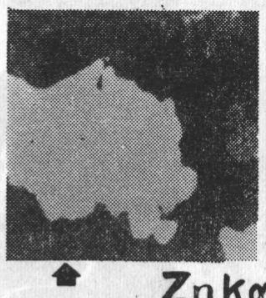

$Z_{n k \alpha}$
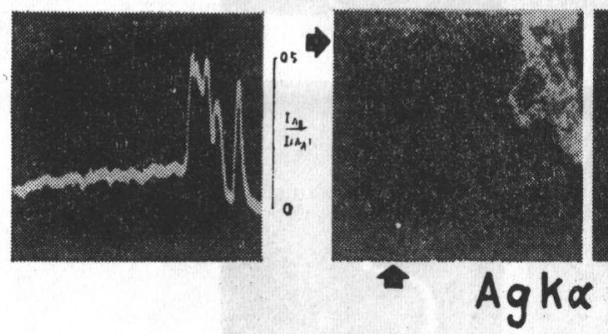

点 分 析

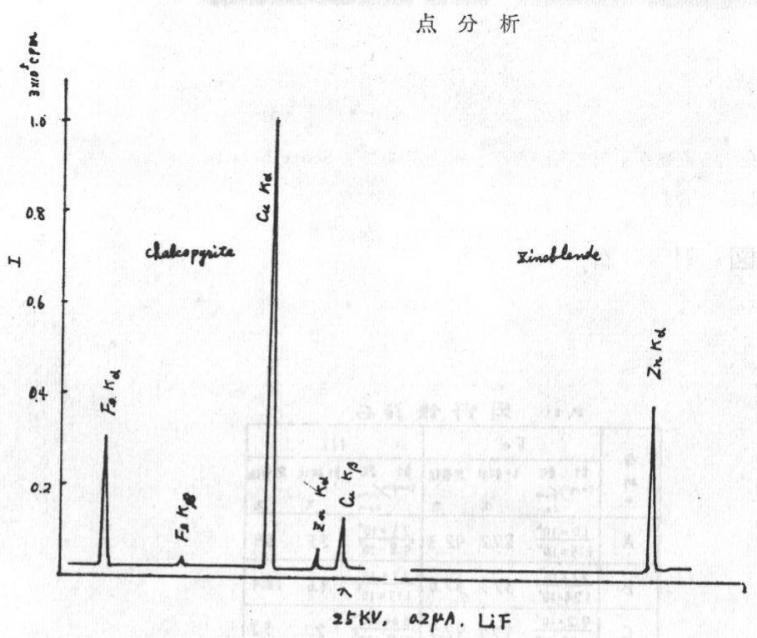

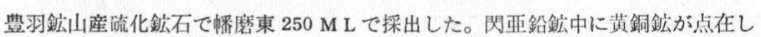
ている。これは顥微鏡観察によつてもわかる部分もあるが、本测定による黄銅鉱 であることを元素の組成からも確認できた。

第12図 硫化鉱
1. 顕微鏡で確認し難い極微細鉱物

2. 隣接鉱物との境界の元素分布および二次的 生成鉱物

3. 龟裂中などの狭雑鉱物

4. 希土類のような他の分析法で困難な試料

5. 単鉱物種中に含有する主成分外の元素の分 布.

6. 鉱物、岩石等で、ある元素の移衝

7. ごく少量産出の釷物

8. 粘土鉱物のごと艺微細鉱物の集合したもの

\section{文献}

1) R. Castaing, A. Guineir, Proceeding of Conference Electron Microscopy at Delft (1949) ; Delft (1950)

2) R. Castaing. Thesis, University of Paris (1951) ; Publication O. N. E. R. A. No 55 (Translated by P. Duwez, D. B. Wittry, California Inst. Tech).

3 ) P. Duncumb, V. E. Cosslett, "Proceeding of Conference on X-ray Microscopy and Microdiograpy" 374, 617 (1957)

4 ) P. Duncumb, Brit. J. Appl phys 10, 420 (1959)

5 ) P. Duncumb, V. E. Cosslett, "Proceeding of Symposium on X-ray Microscopy and X-ray Microanalysis, Stockholm" (1959)

6 ) V. E. Cosslett, P. Dumcumb, Nature 117. 1172 (1956)

7 ) L. S. Birks, E. J. Brooks, Rev, Sci, Instr 29, 709 (1957)

8 ) D.B. Wittry, Thesis, California Inst. Tech (1957)

9) T. Mulvey, J. Sci. Instr 36, 350 (1959)

10）市ノ川竹男、X線マイクロアナライザー、 分析化学 10, 6, 669 (1961)

11) 紀本静雄、X線マイクロアナライザー、金 属物理 8, 86, 127 (1962)

12) A. H. Compton, S. K. Allison, $\mathbf{X}$-rays in Theory and Experiment. (D. Van Nostrand Co. New York), (1957)

13) R. Castaing, J. Descamps, J. Phys. Radium 16, 682 (1955)

14) 藤原鎮男、中村忠晴、分析化学討論会 May (1962)

15) S. Shirai, A. Onoguchi, J. Phys. Soc. Japan 17, 1515 (1962)

16) 藤原鎮男、中村忠晴、村上正弘、日本化学 会16年会講演 (1963)

17) T. O. Ziebold, R. E. Ogilvie, Anal Chem 35, 6, 621 (1963)

18) R. Castaing, "Adovance in Electronics and Electron Physics 13, 317 (1960)

19) L.S. Birks, J. Appl. Phys. 32, 387 (1961)

20）井上勇、中村忠晴、山田幸男、日本分析化 
中 村 忠 睛

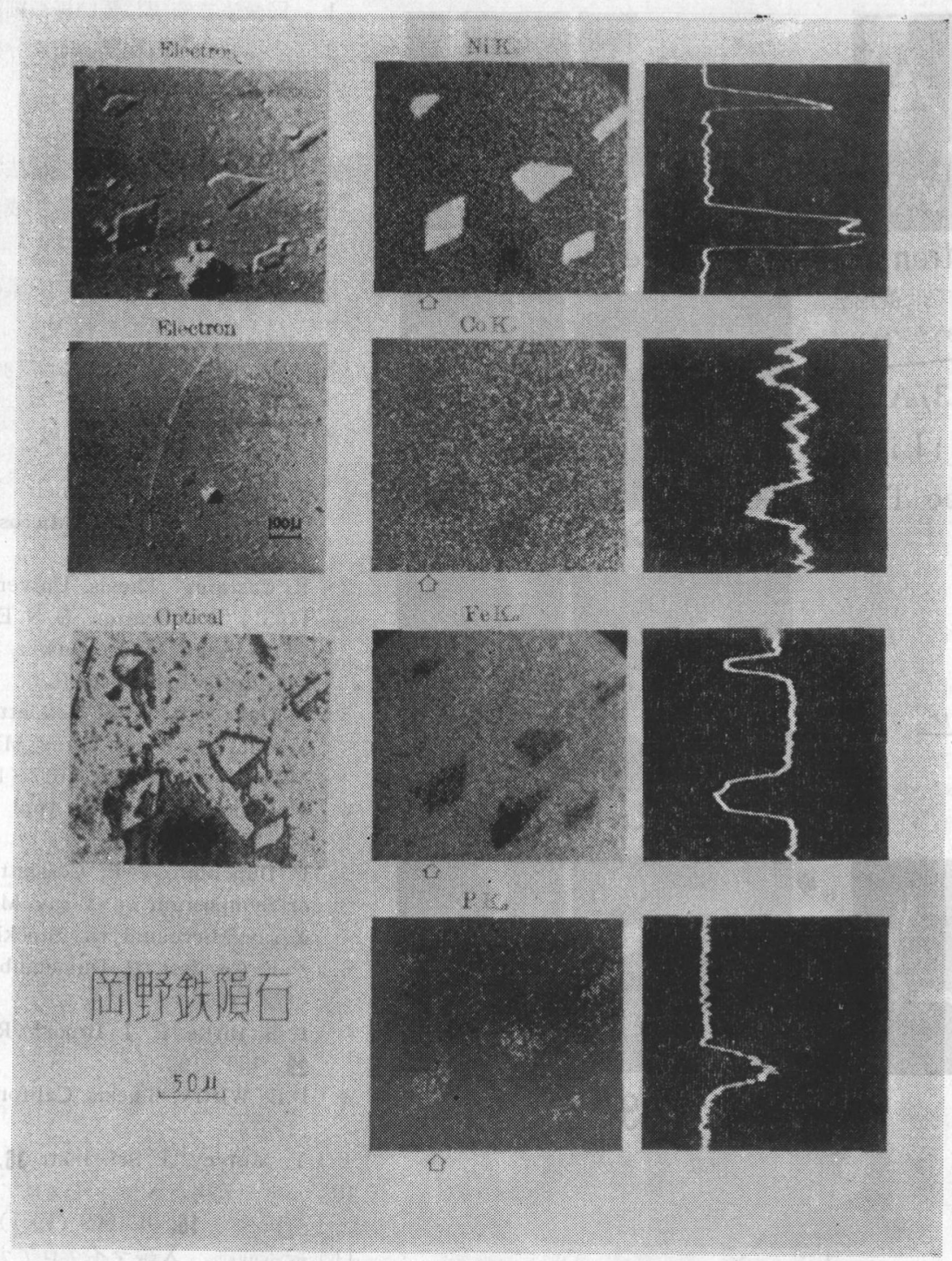

岡野鉄隤石で代表的な Kamacite である。点在する釷物が不明であつたが、本测定により Schreibersite と同定した。共存する微細鉣物種の同定一例として示す。

第13図 隕 石

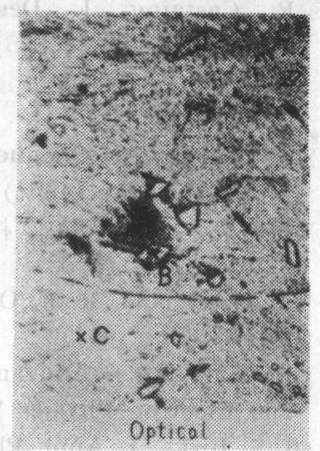

\begin{tabular}{|c|c|c|c|c|c|}
\hline \multirow[b]{2}{*}{$\begin{array}{l}\text { 分 } \\
\text { 新 } \\
\text { 点 }\end{array}$} & \multicolumn{2}{|r|}{$\mathrm{Fe}$} & \multicolumn{3}{|c|}{$\mathrm{Ni}$} \\
\hline & tompion & 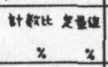 & 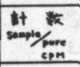 & $\begin{array}{c}\text { to kut } \\
\%\end{array}$ & r. \\
\hline A & $\frac{1.0 \times 10^{6}}{1.15 \times 10^{6}}$ & $\begin{array}{lll}87.2 & 92.3\end{array}$ & $\frac{2.5 \times 10^{4}}{9.8 \times 10^{6}}$ & 2.5 & 6.9 \\
\hline B & $\frac{7.1 \times 10^{7}}{1.24 \times 10^{6}}$ & $57.3 \quad 67.6$ & $\frac{1.1 \times 10^{7}}{1.15 \times 10^{6}}$ & 9.6 & 18.4 \\
\hline C & $\frac{9.2 \times 10^{3}}{1.15 \times 10^{6}}$ & 87.792 .7 & $\frac{2.06 \times 10^{4}}{9.8 \times 10^{8}}$ & 2.1 & 5.8 \\
\hline
\end{tabular}


学:会11年公講演 (1962)

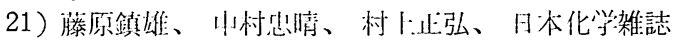
85, 11772 (1964)

22)白丰省䂞、分析機器 Vol 2，4，30（1964）

23) B. Andronopoulos. Bull. Soc. franc. Miner. Crist., 84, 345 (1961)

$24)$ L. S. Birks, E. J. Brooks, I. Adler, C. Milton : Am. Mineral., 44, 974 (1959)

25) H. Bizouard, C. Roering : Geologiska Foreningeus, 80, 309 (1958)

26) F. Permingeat, E Weinryb : Bull. Soc. franc. Miner. Crist., 83, 65 (1960)

27) M. J. Pronvost : ibid., 84, 314 (1961)

$28)$ G. Springe, J. V. P. Long : "Proceeding of Symposium on X-ray Optics and X-ray Microanalysis" (1962)

29）藤原鎮男、中村忠腈、山田幸男：日本化学会 第10 年会予稿集(1961)

30）藤原鎮男、中村婜晴、山田幸男：日本化学:会秋季 講演子禞集 (1961)

31）藤本良規、今井否喜：口本鉱山地所学会第12回予 稿 (1962)

32) 加藤时只、日本鉣物学会講演 (1964)

33) C. Bahezre, M. Capitant, K.D. Phan : Bull. Soc, franc. Miner. Crist., 84, 321 (1961)

34) M. Capitant, K. D. Phan : ibid., 84, 400 (1961)

35) H. Vincienne, P. Salesse : ibid., 84, 430 (1961)

36) 渡辺武夫：日本地斦学会第69年会講演(1962)

37) D. Fauquier : C. R., 252, 3283 (1961)

38) C. Levy, P. Picot: Bull, Soc. franc. Miner. Crist., 84, 312 (1961)

39) F. E. Stumpel : Mineralogical Magazine, 32, 833 (1961)

$40)$ R. Castaing, K. Fredriksson : Geochim. Cosmochim, Acta., 14, 114 (1958)

41) R. E. Maringer, N. A. Richard, A : E. Austin : AIME Trans. Met Soc. 215, 56 (1959)

42) K. D. Phan, M. Capitant : International Symp. on Minning Res., 1, 399 (1962)

43）南英一、村山定男、中村忠晴：日本化学会秋否講 演会 (1962)

44）村山定男、中村忠晴：日本天文兴:会講演（1963）

45）中村忠啨、村山定男、村.上正弘：X線マイクロア ナライザ研少公 (1963)

46) I. Adler, E.J. Dwornik : U.S. Geol. Survey prof. paper 424-B, 263 (1961)

$47)$ D. W. Brentnall, H. J. Axon : J. Iron Steel Inst., 200, 947 (1962)

48) M. Feller, H.H. Uhlig : Geochim. et Cosmochim. Acta, 21, 257 (1961)

49) J. I. Goldstein, R. E. Ogilvie : ibid., 27, 623 (1963)

50) K. keil, K. Fredriksson ; Geochim. Cosmochim. Acta. in press ;

51) P.Pietrokiwsky. J.R. Matichich : "X-ray optics and X-ray Microanalysis" 59 (1963)

52) E. F. Stumpfl, A. M. Clark : Neues Jahrb Mineral Monatsh. 8,240 (1964)

53) D. D. Klemm : Neues Jahrb Mineral Abhandl, 103, 205 (1965)

54) Н. В. Королев : Геохимия, 9, 917 (1964)

55) K. Kell, K. Fredriksson : J Geophys Research 69, 3487 (1964)

56) B. Nagy, C.A. Andersen : Am Mineralogist 49, 1730 (1964)

57) J. F. Lovering : Geochimi et Cosmochimi Acta 28, 1745 (1964)

58) S.J.S. Reed : Geochimi et Cosmochimi Acta 29, 513 (1965)

59) K. Kell, C. A. Andersen : Geochimi et Cosmochimi Acta 29, 621 (1965)

60) P.W. Hodge, F.W. Wright : J Geophys Research 69,2919 (1964)

61) S.J.B. Reed : Geochimi et Cosmochimi Acta 29, 535 (1965) 